\title{
Bahaya Wadah Styrofoam dan Alternatif Penggantinya
}

\author{
Izzah Al Mukminah \\ Program Studi Sarjana Farmasi, Fakultas Farmasi, Universitas Padjadjaran, Sumedang, Jawa Barat. \\ email: izzahlvfam@gmail.com \\ (Submit 29/5/2019, Revisi 16/7/2019, Diterima 18/7/2019)
}

\begin{abstract}
Abstrak
Wadah styrofoam tersusun dari polimer-polimer yang berasal dari bahan kimia aditif. Zat-zat aditif dari wadah ini dapat bermigrasi ke makanan yang dikemas, yang berbahaya bagi manusia karena bersifat karsinogenik. Styrofoam atau busa plastik lazim digunakan sebagai pelindung bahan mudah pecah atau disebut juga fragile. Namun, kini styrofoam menjadi salah satu pilihan bahan pengemas makanan dan minuman. Dalam mini review ini dijelaskan terkait bahan berbahaya yang terkandung di dalam wadah styrofoam dan juga wadah alternatif penggantinya.
\end{abstract}

Kata kunci : styrofoam, polimer, bahan kimia, makanan, minuman

\section{Outline}

- Pendahuluan

- Karakteristik wadah dari styrofoam

- Plasticizer dalam styroform

- Kelebihan dan kekurangan styrofoam

- Zat berbahaya dalam Styrofoam

- Alternatif wadah kemasan lainnya Kesimpulan

- Daftar Pustaka

\section{Pendahuluan}

Zaman sekarang semua orang menginginkan semua hal yang serba praktis contohnya seperti wadah Styrofoam untuk dijadikan wadah makanan yang sekali pakai dapat langsung dibuang.

\section{Karakteristik wadah dari styrofoam}

Wadah styrofoam tersusun dari polimer-polimer yang berasal dari bahan kimia aditif. Zat-zat aditif dari wadah ini dapat bermigrasi ke makanan yang dikemas, yang berbahaya bagi manusia karena bersifat karsinogenik. Styrofoam atau busa plastik lazim digunakan sebagai pelindung bahan mudah pecah atau disebut juga fragile. Namun, kini styrofoam menjadi salah satu pilihan bahan pengemas makanan dan minuman. 
Perlu diketahui, bahwa styrofoam masih termasuk dalam famili plastik. Dengan bahan pembangun yang disebut polisterin, yaitu suatu jenis plastik yang sangat ringan, tembus cahaya, kaku dan murah tetapi cepat rapuh. Karena sifat dari bahan pembangun tersebut, ditambah beberapa bahan-bahan kimia lainnya dan akhirnya akan menghasilkan bentuk styrofoam seperti yang telah kita ketahui sekarang.

\section{Plasticizer dalam styroform}

Apa yang membuat styrofoam menjadi lentur seperti yang bisa kita lihat sekarang? Jadi, di dalam stirena tersebut yang merupakan bahan dasar dan pembangun styrofoam terdapat zat plasticizer.

Zat plasticizer adalah bahan tidak dapat menguap yang ditambah ke dalam pembuatan plastik lalu akan berpengaruh terhadap sifat plastik tersebut yang terbentuk karena akan mengurangi sifat ikatan-ikatan yang sangat kuat yang mengikat atom-atom pembentuk stirena tersebut dan menurunkan ikatan-ikatan kuat.

Plasticizer mempunyai titik didih tinggi dan penambahan plasticizer diperlukan untuk mengatasi sifat rapuh plastik yang disebabkan oleh kekuatan ikatan yang ekstensif.

\section{Kelebihan dan kekurangan styrofoam}

Pertama karena praktis. Orang-orang tidak perlu membawa wadah yang sudah kosong bekas makan atau minuman, dengan wadah styrofoam kita dapat langsung membuah wadahnya. Selain itu wadah Styrofoam juga dapat menahan panas makanan dalam waktu yang lebih lama dibandingkan dengan wadah lain.

Tetapi wadah ini juga bersifat karsinogenik atau beracun jika digunakan berlebihan. Khususnya pada makanan berkuah atau air minum yang memiliki suhu yang tinggi atau panas, dan juga jika dijadikan wadah makanan dalam waktu yang panjang wadah Styrofoam ini makin berbahaya.

\section{Zat berbahaya dalam Styrofoam}

Jadi selain bahan-bahan penyusun styroform yang telah dipaparkan, Styrofoam juga mengandung zat kimia yaitu stirena, butyl hidroksi toluene dan poltirena dan juga CFC.

Zat stiren yang terkandung pada Styrofoam ini yang dapat menyebabkan gangguan pernafasan, iritasi pada kulit, iritasi pada mata pada tingkat rendah dan dapat menyebabkan kanker pada penggunaan tingkat tinggi. Zat stirena dan zat-zat aditif lainnya yang terkandung pada Styrofoam ini dapat berpindah dari Styrofoam ke makanan.

Zat-zat yang ada dalam Styrofoam jika masuk ke dalam makanan menjadi racun dan akan menyebabkan gangguan pada system endokrin dan juga sistem reproduksi. Oleh sebab itu penggunaan Styrofoam dapat menyebabkan makanan menjadi beracun. Dan jika semakin panas makanan atau minuman yang disimpan dalam wadah Styrofoam menyebabkan semakin cepat zatzat beracun pada Styrofoam berpindah ke makanan. Hal ini yang menyebabkan pemakaian Styrofoam sebagai wadah makanan atau minuan harus dibatasi karena sifat karsinogeniknya. 
Zat Butil hidroksi toluena adalah salah satu contoh dari zat plasticizer yang memberi sifat kepada plastik. Merupakan zat yang hanya bisa larut di dalam lemak dan turunan dari fenol.

\section{Alternatif wadah kemasan lainnya}

Memangnya kemasan untuk makan dan minum cuma Styrofoam saja. Tidak, bukan? Nah, demi menjunjung tinggi prinsip ramah lingkungan, banyak sekali alternatif untuk menggantikan sosok styrofoam ini. Apa contohnya? Cara nomor satu adalah dengan selalu memakai piring atau tempat bekal makan dan selalu membawa botol minum kemanapun.

Baca : Mahasiswa Olah Kulit Jeruk Jadi Granul Efervescent Pembasmi Jentik Nyamuk Alternatif nomor dua adalah dengan memakai bahan yang juga plastik tetapi lebih ramah lingkungan yaitu plastic dengan label polietilen, yaitu bahan-bahan plastik dengan label $3 R$ : recycle, reuse and reduce.

Polietilen adalah polimer yang unsur-unsur atom karbonnya bergabung melalui ikatan kovalen yang kuat. Antara rantai satu dengan yang lain dihubungkan oleh ikatan Van der Waals yang bersifat sangat lemah daripada ikatan- ikatan lainnya yang menghubungkan atom satu dengan lainnya sehingga terbentuklah polietilen yang kita kenal dengan plastik.

Ikatan lemah tadi membuat sifat dari plastik menjadi plastis atau melayang-layang seperti kain. Tetapi perlu diingatkan lagi, bahwa alternatif nomor satu adalah yang paling ramah lingkungan dan dapat mengurangi limbah-limbah yang dapat berdampak buruk bagi lingkungan. Walaupun alternative ini bisa dibilang tidak praktis tetapi sangat menghindari dari penyakit-penyakit yang akan ditimbulkan dari Styrofoam.

Pemerintah Kota New York dan San Francisco resmi mengeluarkan larangan penggunaan kemasan sekali pakai yang terbuat dari styrofoam. Kebijakan tersebut diikuti oleh beberapa kota lain seperti Seattle, Los Angeles, Portland, dan Oregon.

Di Inggris, Oxford menjadi kota pertama yang menerapkan larangan penggunaan styrofoam sejak 2015. Semua restoran dan warung makanan diharuskan menggunakan kemasan yang ramah lingkungan atau yang bisa didaur ulang.

\section{Kesimpulan}

Saat ini, wadah Styrofoam banyak digunakan sebagai wadah makanan dikarenakan kepraktisan pemakaian yang bisa langsung dibuang. Akan tetapi, dibalik kepraktisannya Styrofoam terkandung zat karsinogenik atau beracun jika digunakan berlebihan. Oleh karena itu, diperlukan alternative pengganti seperti memakai bahan yang juga plastik tetapi lebih ramah lingkungan yaitu plastic dengan label polietilen, yaitu bahan-bahan plastik dengan label 3R : recycle, reuse and reduce.

\section{Daftar Pustaka}

Sulchan, M. dan Endang N. W. 2007. Keamanan Pangan Kemasan Plastik dan Styrofoam. Majalah Kedokteran Indonesia Vol. 57 No. 2 : 54-59.

http://eprints.polsri.ac.id/1925/3/BAB\%20II\%20Nanda.pdf

Pelarangan Styrofoam di Berbagai Negara. https://www.pikiran-rakyat.com/hidupgaya/2016/11/12/pelarangan-styrofoam-di-berbagai-negara-384558 